Studia nad Autorytaryzmem i Totalitaryzmem 43, nr 4 Wrocław 2021

https://doi.org/10.19195/2300-7249.43.4.12

\author{
MARCIN PODLEŚ \\ ORCID: 0000-0002-4365-7569 \\ Uniwersytet Wrocławski \\ marcin.podles@uwr.edu.pl
}

\title{
Instytucja osobowości prawnej w okresie PRL jako narzędzie ograniczania autonomii jednostek przez państwo autorytarne
}

\author{
Slowa kluczowe: osobowość prawna, osoba prawna, autorytaryzm, jednostka gospodarki uspo- \\ łecznionej.
THE REGULATION OF LEGAL PERSONALITY DURING THE COMMUNIST PERIOD IN POLAND AS A MEANS OF LIMITING THE AUTONOMY OF INDIVIDUALS BY AN AUTHORITARIAN STATE

\begin{abstract}
The purpose of this paper was to analyze how the regulation of legal personality by positive law affected the rights and freedoms of individuals in the period of the Polish People's Republic. The possession of legal personality leads to the empowerment of an organization and facilitates it by pooling resources to achieve a certain goal. Having legal personality also gives an entity a certain autonomy vis-à-vis other entities, including its members and the state. The analysis has shown that in the period of the Polish People's Republic, positive law was deliberately used to limit the possibility of creating entities with their own legal personality. The formal concept of a legal person was used instrumentally as a tool to impede the possibility of building an organization outside state control. It also led to a structurally incorrect and practically questionable recognition of the judicial capacity of entities that did not have legal personality. In addition, using the concept of an economic unit in the area of economy, a functional criterion was adopted to determine the participants of economic turnover, which also broke with the traditionally adopted in this respect approach based on legal personality. This led some of the representatives of civil law doctrine at that time to consider the institution of legal personality as useless, which testified to the fact that the legal environment and the applied mechanisms typical of an authoritarian state suppressed any autonomy and independence of interest underlying a separate legal personality.
\end{abstract}

Keywords: legal personality, legal person, authoritarianism, socialized economic unit. 


\section{Wprowadzenie}

Przedmiotem opracowania jest analiza zagadnienia, jak w okresie Polskiej Republiki Ludowej regulacja osobowości prawnej przepisami prawa pozytywnego wpływała na prawa i wolności jednostek. Posiadanie osobowości prawnej (podmiotowości) przez daną organizację (jednostkę organizacyjną) prowadzi bowiem do jej upodmiotowienia i ułatwia przez to prowadzenie i rozwijanie prowadzonej działalności - gromadzenie środków dla osiągania określonego celu. Posiadanie osobowości prawnej stwarza też danej organizacji pewną autonomię wobec innych podmiotów, w tym wobec jej członków oraz państwa. W prawie prywatnym termin osoba prawna jest zaś tradycyjnie i aktualnie uznawany za jedno z podstawowych określeń ${ }^{1}$. Istota osoby prawnej jest na przełomie dziejów różnie charakteryzowana, przy czym dla polskiej nauki prawa szczególne znaczenie ma koncepcja stworzona przez Romana Longchampsa de Bériera, uznająca osobę prawną za twór społeczny posiadający określony własny i uznawany interes ${ }^{2}$.

W opracowaniu zaprezentowane zostaną obowiązujące w okresie PRL przepisy prawa odnoszące się do osobowości prawnej i ich konsekwencje dla uznawania podmiotowości prawnej jednostek organizacyjnych. Przywołane zostanie też pojęcie jednostki gospodarki jako kategoria pojęciowa charakterystyczna dla prawa okresu PRL ${ }^{3}$.

\section{Regulacja osobowości prawnej w okresie PRL}

W Polsce po drugiej wojnie światowej materię osobowości prawnej uregulowano w ustawie - przepisy ogólne prawa cywilnego ${ }^{4}$. Nie uzależniano jednak posiadania osobowości prawnej od wyraźnego jej nadania przez ustawodawcę. Również we wcześniej obowiązujących przepisach z okresu dwudziestolecia międzywojennego nie było normatywnej definicji osoby prawnej, a ówczesna doktryna odwoływała się przede wszystkim do elementów konstrukcyjnych i cech, które posiadały jednostki nazywane przez konkretne przepisy osobami prawnymi, jednocześnie uznając zasadę numerus clausus typów podmiotów prawa ${ }^{5}$. Jednakże już projekt kodeksu cywilnego z 1954 roku ujawnił tendencję do reglamentowania podmiotowości i zdolności prawnej w stosunku do „organizacji niebędących

1 Tak przykładowo J. Frąckowiak, [w:] Prawo cywilne - część ogólna, t. 1, red. M. Safjan, Warszawa 2012, s. 1118 n.; por. także dokonaną przez J. Frąckowiaka prezentację teorii opisujących istotę osoby prawnej.

2 R. Longchamps de Bérier, Studia nad istota osoby prawniczej, Lwów 1911, s. 147 n.

3 Ze względu na ramy objętościowe poza zakresem opracowania pozostawiono zagadnienie specjalnej zdolności prawnej osób prawnych, które zasługuje na odrębne potraktowanie.

${ }^{4}$ Ustawa z dnia 18 lipca 1950 roku (Dz.U. z 1950 r. Nr 34, poz. 311).

5 Por szerzej S. Grzybowski, Ze studjów nad osobowościa prawnq. Powstanie, rozwiąanie i likwidacja spótdzielni, Kraków 1930. 


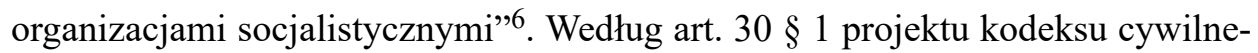
go, „organizacje socjalistyczne” miały mieć bowiem zdolność prawną w zakresie uregulowanym $\mathrm{w}$ ustawach oraz $\mathrm{w}$ opartych na nich statutach, natomiast „organizacjom niebędącym organizacjami socjalistycznymi” zdolność prawna przysługiwać miała w wypadkach przewidzianych w przepisach szczególnych. Przyjęte finalnie w kodeksie cywilnym uregulowanie wymagało zaś w każdym przypadku wywodzenia osobowości prawnej z wyraźnego przepisu ustawy ${ }^{7}$. Zgodnie $\mathrm{z}$ treścią art. $33 \mathrm{kc}$ w wersji pierwotnej za osoby prawne uznano następujące ,jednostki gospodarki uspołecznionej": Skarb Państwa, przedsiębiorstwa państwowe i ich zjednoczenia oraz banki państwowe ${ }^{8}$. Ponadto na podstawie art. $33 \S 1 \mathrm{kc} \mathrm{w}$ jego pierwotnej wersji osobowość prawną przyznano spółdzielniom i ich związkom oraz kółkom rolniczym i ich związkom. Inne ,państwowe jednostki organizacyjne” oraz ,inne organizacje społeczne ludu pracującego" miały być wyposażone w osobowość prawną, gdy przepisy szczególne im ją przyznały. Również ,jednostki organizacyjne niebędące jednostkami gospodarki uspołecznionej” mogły być osobami prawnymi, o ile przepisy szczególne przyznawałyby im osobowość prawną (art. $33 \S 2 \mathrm{kc}$ w pierwotnej wersji). Dodatkowo osobowość prawna uzależniona została od szeregu przesłanek natury formalnej, w tym od wymogu rejestracji (art. $37 \mathrm{kc}$ w pierwotnej wersji) ${ }^{9}$.

W okresie PRL nie zdecydowano się na wybór metody ogólnego formułowania cech osób prawnych. Odstąpiono od materialnego ich określania i wyliczania w przepisach swoistego katalogu ich cech - obierając rozwiązanie wymagające wyraźnego przyznania danemu typowi jednostki organizacyjnej osobowości prawnej przez ustawodawce $\mathrm{w}$ przepisie prawa ${ }^{10} \mathrm{i}$ tym samym przyjmując formalne ujęcie osoby prawnej ${ }^{11}$. Towarzyszyła temu istotna powściągliwość ustawodawcy w przyznawaniu osobowości prawnej jednostkom organizacyjnym, co spotykało się z krytyką doktryny prawa cywilnego ${ }^{12}$. Aleksander Wolter zarzucił ustawodawcy na przykładzie jednostek budżetowych, iż nadając określonym jednostkom osobowość prawną, kierował się względami całkowicie leżącymi poza sferą

${ }^{6}$ Por. A. Wolter, Zagadnienie osobowości prawnej w projekcie kodeksu cywilnego Polskiej Rzeczypospolitej Ludowej, [w:] Materiały dyskusyjne do projektu kodeksu cywilnego Polskiej Rzeczypospolitej Ludowej. Materiaty Sesji Naukowej, Warszawa 1955, s. 81-82.

7 A. Wolter, Osobowość prawna jednostek budżetowych, „Państwo i Prawo” 1956, nr 11, s. $824-825$.

${ }^{8}$ Ustawa z dnia 23 kwietnia 1964 roku - Kodeks cywilny (Dz.U. z 1964 r. Nr 16, poz. 93), dalej: kc.

${ }^{9}$ Por. także A. Stelmachowski, Czy kryzys osoby prawnej?, „Ruch Prawniczy, Ekonomiczny i Socjologiczny" 3, 1960, s. 200.

10 Por. Z. Radwański, Podmioty prawa cywilnego w świetle zmian kodeksu cywilnego przeprowadzonych ustawa z dnia 14 lutego 2003 r., „Przegląd Sądowy” 2003, nr 7-8, s. 5.

11 Por. A. Stelmachowski, Wstęp do teorii prawa cywilnego, Warszawa 1998, s. 162.

12 Por. przykładowo: A. Klein, Ewolucja instytucji osobowości prawnej, [w:] Tendencje rozwoju prawa cywilnego, red. E. Łętowska, Warszawa 1983, s. 61; A. Wolter, Nowy projekt kodeksu cywilnego, „Państwo i Prawo” 1962, nr 2, s. 212. 
prawa cywilnego ${ }^{13}$. W jego ocenie za przymiotem osobowości prawnej powinna stać zdolność do uczestniczenia w obrocie cywilnoprawnym, dająca się streścić jako zdolność prawna i do czynności prawnych, a każda jednostka organizacyjna, która ma te cechy, powinna być uznana za osobę prawną ${ }^{14}$. Wolter posługiwał się przy tym określeniem „ułomnych osób prawnych” ${ }^{15}$. Osoba prawna w nauce prawa prywatnego definiowana była często poprzez posiadanie atrybutu zdolności prawnej ${ }^{16}$. W ówczesnej doktrynie prawa podkreślano jednak również różnorodność stosunków społeczno-gospodarczych wymagających powoływania do życia „tworów o charakterze kolektywnym, które jednak nie mają wyraźnie przyznanej osobowości prawnej"17. Wskazywano przy tym na powstawanie pozbawionych osobowości prawnej „,centrów działalności, którym prawo nadaje różną organizację, a na ich członków nakłada prawa i obowiązki odnoszące się zarówno do ich stosunków wewnętrznych, jak i stosunków zewnętrznych"18. W końcu część przedstawicieli polskiej doktryny stanęła na stanowisku, iż określone jednostki organizacyjne posiadają podmiotowość prawną, pomimo iż żaden przepis szczególny im jej nie przyznaje ${ }^{19}$. Treść art. 33 kc próbowano także interpretować rozszerzająco w ten sposób, iż przepisy szczególne, do których odsyłał art. $33 \mathrm{kc}$, miały przyznawać osobowość prawną także pośrednio — poprzez odpowiednie materialne ukształtowanie danej jednostki organizacyjnej ${ }^{20}$. Przywołane poglądy o pośrednim przyznawaniu osobowości prawnej były jednak z normatywnego punktu widzenia trudne do zaakceptowania na bazie ówcześnie obowiązujących przepisów, ponieważ prowadziły do przejęcia typu regulacji świadomie odrzuconego przez ustawodawcę ${ }^{21}$. Według Stanisława Grzybowskiego poza osobami prawnymi i fizycznymi kodeks cywilny nie znał żadnych innych osób prawa cywilnego $^{22}$. Również Alfred Ochanowicz argumentował, iż kodeks cywilny nie zawiera żadnej wzmianki o organizacjach niemających osobowości prawnej, a mimo to mogących we własnym imieniu nabywać prawa i zaciągać zobowiązania ${ }^{23}$.

13 Por. A. Wolter, Osobowość..., s. 824-825.

14 Ibidem.

15 Por. A. Wolter, Prawo cywilne. Zarys części ogólnej, Warszawa 1967, s. 167.

16 Ibidem, s. 162.

17 Por. H. Dzierzgwa, Glosa do orzeczenia Sądu Najwyższego z dnia 7.06.1957, IV CR 185/56, „Orzecznictwo Sądów Polskich i Komisji Arbitrażowych” 1958, poz. 260, s. 614.

18 Ibidem.

19 Tak między innymi A. Wolter, Prawo cywilne..., s. 169.

20 Por. A. Klein, op. cit., s. 107 n. Autor ten wyróżniał na podstawie wyodrębnionych przez siebie kryteriów materialnych osoby prawne wyraźnie nazwane przez porządek prawy i osoby prawne nienazwane.

21 Tak trafnie: Z. Radwański, Prawo cywilne - czesść ogólna, Warszawa 1994, s. 144-145.

22 Por. S. Grzybowski, Kilka uwag o rzekomych podmiotach stosunków cywilnoprawnych, „Studia Cywilistyczne” 27, 1976, s. 3-7. Autor ten uznał jednak potencjalną możliwość stworzenia teoretycznej konstrukcji opierającej się na koncepcji „ułomnej osoby prawnej”, lecz równocześnie traktował ją jako sprzeczną z obowiązującymi w owym czasie przepisami.

${ }^{23}$ Por. A. Ohanowicz, Zobowiązania. Zarys wedtug kodeksu cywilnego, Warszawa-Poznań 1965 , s. 35 n. 
W okresie PRL próbowano przezwyciężać trudności wynikające $\mathrm{z}$ celowo oszczędnego dysponowania w przepisach szczególnych przymiotem osobowości prawnej przez ustawodawcę poprzez szerokie ujmowanie zdolności sądowej wykraczającej poza krąg osób prawnych. We wczesnym orzecznictwie podkreślano, iż ,rozwój stosunków społeczno-gospodarczych wymaga przyznania zdolności sądowej niektórym tworom społecznym wykazującym dostateczny stopień wyodrębnienia i samodzielności, mimo iż nie są one uznane za osoby prawne"24. Sąd Najwyższy uzasadnił swoją linię orzeczniczą sprzecznością między istniejącym ówcześnie systemem nabywania osobowości prawnej a potrzebami wywołanymi rozwojem stosunków społecznych, politycznych i gospodarczych ${ }^{25}$. W ten sposób uznano w orzecznictwie zdolność sądową, pomimo braku osobowości prawnej, partii politycznych, spółek jawnych oraz komitetów elektryfikacyjnych $w_{\text {wi }}{ }^{26}$. Andrzej Stelmachowski spostrzegł tutaj prawidłowość, że jeżeli sądy czuły się zmuszone do szerszego dopuszczania do udziału w procesie jednostek nieposiadających osobowości prawnej, to czyniły to przez konstrukcję zdolności sądowej bez osobowości prawnej ${ }^{27}$. Stosowane rozwiązanie przyznające zdolność prawną jednostkom organizacyjnym nieposiadającym zdolności prawnej zrywało jednak tradycyjny i logiczny związek między zdolnością prawną i sądową, a w konsekwencji nie służyło zasadzie bezpieczeństwa obrotu prawnego ${ }^{28}$. Miało charakter raczej rozwiązania prowizorycznego - poszukiwania praktycznego rozwiązania w sytuacji niedostatecznego nadawania osobowości prawnej.

Warto podkreślić, że w przepisach kodeksu postępowania cywilnego ustawodawca usankcjonował co prawda stan istnienia zdolności sądowej bez osobowości prawnej, ale możliwość taką literalnie ograniczył jedynie do „organizacji społecznych ludu pracującego dopuszczonych do działania na podstawie obowiązujących przepisów" 29 .

24 Por. orzeczenie Sądu Najwyższego z dnia 21 marca 1964 roku, I CR 697/62, „Orzecznictwo Sądów Polskich i Komisji Arbitrażowych” 1965, poz. 95.

${ }^{25}$ Ibidem.

26 Por. A. Stelmachowski, Czy kryzys..., s. 199-200.

27 Por. ibidem, s. 199. Na temat kształtowania się relacji pojęcia zdolności sądowej do pojęcia zdolności prawnej por. H. Mądrzak, Zdolność prawna a zdolność sądowa (uwagi wokót upodmiotowienia niektórych struktur organizacyjnych $w$ prawie cywilnym i procesowym), [w:] II Kongres Notariuszy Rzeczypospolitej Polskiej. Referaty i opracowania, Poznań-Kluczbork 1999, s. 177 n.; por. także A. Stelmachowski, Czy kryzys..., s. 207.

28 Tradycyjnie zdolność sądową odnoszono zawsze do podmiotu prawnego - por. na przykład W. Siedlecki, Zarys postępowania cywilnego, Warszawa 1968, s. 111; por. także T. Misiuk, Pojęcie organizacji ludu pracującego, „Państwo i Prawo” 1969, nr 1, s. 28. Autorka trafnie podniosła, że aby dochodzić we własnym imieniu określonych praw, trzeba być podmiotem tych praw, co wyklucza istnienie podmiotów wyposażonych w zdolność sądową, a nieposiadających zdolności prawnej.

29 Por. art. $64 \S 2$ k.p.c. w pierwotnej wersji — ustawa z dnia 17 listopada 1964 roku (Dz.U. z 1964 r. Nr 43, poz. 296); por. także T. Misiuk, Glosa do uchwaty z 7 VII 1966, III PZP 11/66, „Państwo i Prawo” 1967, nr 6, s. 1029-1030. Autorka ta postawiła tezę, że przyznanie takim organizacjom przez przepisy procedury cywilnej zdolności sądowej implikuje uznanie ich zdolności 


\section{Pojęcie jednostki gospodarki jako substytut pojęcia kupca (przedsiębiorcy)}

Odchodzenie przez ustawodawcę od ujęcia podmiotowego uczestników obrotu widoczne było również w obszarze gospodarki, gdzie centralne miejsce zajmowało pojęcie jednostki gospodarki. Po drugiej wojnie światowej niezmiernie wzrosła też rola państwa w gospodarce, w szczególności w wyniku wydania dekretu z dnia 3 stycznia 1946 roku o przejęciu na własność państwa podstawowych gałęzi gospodarki narodowej ${ }^{30}$. Państwo stało się w ten sposób właścicielem wielkiej ilości przedsiębiorstw przemysłowych, górniczych, komunikacyjnych, ubezpieczeniowych, a częściowo również handlowych ${ }^{31}$. Wraz z wejściem w życie kodeksu cywilnego został też uchylony kodeks handlowy ${ }^{32}$. Obszar zastosowania spółek stał się niewielki, co było pochodną przede wszystkim reglamentacji podejmowania działalności gospodarczej, z jednej strony ${ }^{33}$, a z drugiej — preferowania przez ustawodawcę innych form działalności niż spółki, na obszarze szerokiej aktywności gospodarczej państwa oraz jego emanacji ${ }^{34}$.

prawnej, chociaż równocześnie wyraziła wątpliwość, na ile to uregulowanie proceduralne jest zgodne z zasadami prawa cywilnego.

30 Dz.U. z 1946 r. Nr 3, poz. 17.

31 S. Janczewski, Prawo handlowe, wekslowe i czekowe, Warszawa 1946, s. 46. Zrodziło to potrzebę wyodrębnienia przedsiębiorstwa państwowego jako formy prowadzenia działalności gospodarczej - por. dekret z dnia 3 stycznia 1947 roku o tworzeniu przedsiębiorstw państwowych (Dz.U. z 1947 r. Nr 8, poz. 42); dekret z dnia 28 października 1950 roku o przedsiębiorstwach państwowych (Dz.U. z 1960 r. Nr 18, poz. 111), ustawę o przedsiębiorstwach państwowych, ustawę z dnia 21 maja 1948 roku o przedsiębiorstwach państwowo-spółdzielczych (Dz.U. z 1948 r. Nr 30, poz. 201) oraz ustawę z dnia 25 września 1981 roku o przedsiębiorstwach (Dz.U. z 1981 r. Nr 24, poz. 122). Stanowiło to zmianę w stosunku do okresu Drugiej Rzeczypospolitej, gdzie konkretne przedsiębiorstwa tworzone były w drodze specjalnych ustaw lub dekretów.

32 Por. art. VI $\S 1$ ustawy z dnia 23 kwietnia 1964 roku (Dz.U. z 1964 r. Nr 16, poz. 94) — przepisy wprowadzające kodeks cywilny, przy czym jednocześnie utrzymano w mocy część przepisów kodeksu handlowego.

33 Por. Ustawa z dnia 1 lipca 1958 roku o zezwoleniach na wykonywanie przemysłu, rzemiosła, handlu i niektórych usług przez jednostki gospodarki nieuspołecznionej (Dz.U. z $1958 \mathrm{r}$. $\mathrm{Nr} 45$, poz. 224), Ustawa z 8 czerwca 1972 roku o wykonywaniu i organizacji rzemiosła (Dz.U. Nr 4, poz. 20) oraz Ustawa z dnia 18 lipca 1974 roku o wykonywaniu handlu oraz niektórych innych rodzajów działalności przez jednostki gospodarki nieuspołecznionej (Dz.U. z 1974 r. Nr 27, poz. 158).

34 Por. S. Włodyka, Prawo gospodarcze. Zarys systemu. Część ogólna, t. 1, Warszawa 1981, s. 201. Formy trwałego współdziałania stanowiły dla sektora państwowego — zjednoczenia, kombinaty, przedsiębiorstwa prowadzące i patronackie; dla sektora spółdzielczego — związki spółdzielnie i centralne związki spółdzielni; dla pozarolniczego sektora nieuspołecznionego - spółdzielnie rzemieślnicze oraz przymusowe organizacje rzemiosła oraz prywatnego handlu - por. W. Góralczyk, [w:] Z problematyki skuteczności prawa gospodarczego i finansowego, Warszawa 1987, s. 133. W obszarze współpracy międzynarodowej w ramach RWPG stosowano konstrukcję „,wspólnego przedsiębiorstwa", która mogła przebierać różne formy prawne, w tym formy państwowych spółek akcyjnych — por. A. Janik, Osobowość prawna wspólnych przedsiębiorstw krajów RWPG, „Państwo i Prawo” 1977, s. $91 \mathrm{n}$. 
W takich okolicznościach głównymi uczestnikami obrotu profesjonalnego stały się tak zwane jednostki gospodarki ${ }^{35}$. Pojęcie ,jednostki gospodarczej” (,,jednostki gospodarki") nie było normatywnie zdefiniowane, co powodowało trudności w jednoznacznym określeniu granic tego pojęcia ${ }^{36}$. Doktryna konstruowała je zwykle szeroko, obejmując nim każdą odpowiednio wyodrębnioną jednostkę organizacyjną powołaną do prowadzenia stałej działalności gospodarczej i specjalnie pod tym kątem ukształtowanej ${ }^{37}$. Jednostki gospodarki ujmowano zatem funkcjonalnie (a nie podmiotowo), a ponadto podlegały one różnym klasyfikacjom i podziałom. Zasadnicze znaczenie przypisywano przy tym podziałowi jednostek gospodarki ze względu na charakter własności stanowiącej podstawę ich działalności ${ }^{38}$. W związku z tym wyróżniano ,jednostki gospodarki uspołecznionej”, ,jednostki gospodarki nieuspołecznionej” oraz ,jednostki mieszane”, chociaż w obrocie występowały przede wszystkim jednostki gospodarki uspołecznionej (j.g.u. $)^{39}$. Z kolei do jednostek gospodarki nieuspołecznionej zaliczano — nadal posługując się ujęciem funkcjonalnym — zakłady rzemieślnicze, indywidualne gospodarstwa rolne, a także prywatne przedsiębiorstwa w dziedzinie handlu, usług i przemysłu ${ }^{40}$. Jednostkom gospodarki nieuspołecznionej przypadało jednakże w obrocie jedynie marginalne znaczenie ${ }^{41}$. $\mathrm{Z}$ pojęciem tym łączono występowanie podmiotowości prawnej, ale przysługiwać ona miała albo właścicielowi danej jednostki - jak w odniesieniu do zakładów rzemieślniczych czy przedsiębiorstw jednoosobowych — bądź samej tej jednostce ${ }^{42}$.

Wąskie przyznawanie osobowości prawnej, centralizacja władzy oraz stosowanie innych kategorii pojęciowych spowodowało, że w doktrynie formułowane były podglądy wręcz o nieprzydatności pojęcia osoby prawnej ${ }^{43}$. Przykładowo nawet $\mathrm{w}$ odniesieniu do przedsiębiorstw państwowych, formalnie w okresie

35 S. Włodyka, op. cit., s. 18-19.

36 W. Góralczyk, [w:] Z problematyki..., s. 142.

37 S. Włodyka, op. cit., s. 105; por. także ujęcie jednostki gospodarki uspołecznionej na gruncie art. 1 oraz art. $33 \mathrm{kc}$ przed zmianami dokonanymi ustawą o zmianie kodeksu cywilnego z dnia 28 lipca 1990 roku (Dz.U. z 1990 r. Nr 55, poz. 321).

38 S. Włodyka, op. cit., s. 105.

39 Por. Z. Gordon, [w:] idem et al., Prawo obrotu gospodarczego, Warszawa 1980, s. 25; S. Włodyka, op. cit., s. 106. Zgodnie z art. 3 ust. 1 pkt 6 Ustawy z dnia 23 października 1975 roku o Państwowym Arbitrażu Gospodarczym (Dz.U. z 1975 r. Nr 34, poz. 183) Państwowemu Arbitrażowi Gospodarczemu podlegały spółki, w których państwo lub wymienione w tej ustawie jednostki państwowe, spółdzielcze lub społeczne posiadały udział wynoszący ponad 50\% kapitału zakładowego. Kryterium kapitału zakładowego mogło być oceniane jedynie wśród spółek kapitałowych, ponieważ w spółkach osobowych instytucja kapitału zakładowego nie występowała.

40 S. Włodyka, op. cit., s. 107.

41 W. Siuda, [w:] J. Kufel, W. Siuda, Prawo gospodarcze dla ekonomistów, Warszawa-Poznań 1980, s. 85.

42 S. Włodyka, op. cit., s. 119.

43 Por. przykładowo E. Rzepka, Z problematyki osobowości prawnej, „Nowe Prawo” 7-8, 1978, s. 1128. 
PRL w osobowość prawną wyposażonych, kwestionowano znaczenie nadania tej osobowości ze względu na daleko idące podporządkowanie przedsiębiorstw państwowych ich jednostkom nadrzędnym, powodujące całkowite zredukowanie ich samodzielności ${ }^{44}$. Andrzej Stelmachowski podnosił, że cel organizacji nie zależy od woli danego przedsiębiorstwa, lecz od założeń i zadań planowych, co wynikało z oparcia gospodarki PRL o plany gospodarcze (centralne planowanie) oraz obowiązywania zasady jednolitego funduszu własności państwowej ${ }^{45}$. W efekcie nazwał on osobę prawną „formą pozbawioną istotnej treści”46.

\section{Podsumowanie}

W okresie PRL celowo wykorzystywano prawo pozytywne do ograniczania możliwości tworzenia jednostek organizacyjnych wyposażonych we własną osobowość prawną i - co za tym idzie - zdolność prawną, które mogłyby na tej podstawie działać w oparciu o własną autonomię, również w jakiś sposób niezależnie w stosunku do państwa. Samo przyjęcie formalnej koncepcji osoby prawnej - odmiennie niż przyjmowano to w okresie Drugiej Rzeczypospolitej można ocenić z punktu widzenia potrzeb praktyki pozytywnie, ponieważ usuwa wątpliwości co do charakteru prawnego danej jednostki organizacyjnej. Odpadają dzięki temu wątpliwości, czy mamy do czynienia z osobą prawną ze względu na jej konkretne cechy materialne ${ }^{47}$. Przy formalnej koncepcji osoby prawnej nie może jednak dochodzić do wykorzystywania nadawania osobowości prawnej w sposób instrumentalny jako narzędzia o charakterze autorytarnym do utrudniania możliwości budowania organizacji poza kontrolą państwa. Stan taki prowadził też do niepoprawnego konstrukcyjnie i wątpliwego praktycznie uznawania zdolności sądowej jednostek organizacyjnych, które nie posiadały osobowości prawnej. Dodatkowo, posługując się w obszarze gospodarki pojęciem jednostki gospodarki, przyjmowano kryterium funkcjonalne dla określania uczestników

44 A. Stelmachowski, Czy kryzys..., s. 205 n.

45 Ibidem; w zakresie zasady jedności własności państwowej w odniesieniu do osobowości prawnej przedsiębiorstw państwowych por. także: C. Przymusiński, Jeszcze jedna próba pogodzenia zasady jedności własności państwowej z zasada osobowości prawnej przedsiębiorstw państwowych, „Przegląd Ustawodawstwa Gospodarczego” 1966, nr 3, s. 93-94. Autor ten, odwołując się do przykładu z NRD, wskazuje, że „niechętnie używa się tam frazeologii z zakresu prawa cywilnego”.

46 A. Stelmachowski, Czy kryzys..., s. 208-209; krytycznie wobec takiego wniosku między innymi E. Łętowska, Samodzielność przedsiębiorstw i ich osobowość prawna, „Przegląd Ustawodawstwa Gospodarczego" 1971, nr 11, s. 369.

47 Za przeciwieństwo formalnej koncepcji osoby prawnej uznaje się metodę ogólnego formułowania cech osób prawnych, gdzie istnienie osobowości prawnej ocenia się przez pryzmat posiadanych przez daną jednostkę organizacyjną cech, co bywać może źródłem niepewności dla obrotu gospodarczego - por. A. Kubiak-Cyrul, [w:] Kodeks cywilny. Komentarz, red. M. Załucki, Warszawa 2020 , komentarz do art. 33, II, nb 7. 
obrotu gospodarczego, co także zrywało z tradycyjnie przyjmowanym ujęciem podmiotowym. Część ówczesnej doktryny prawa cywilnego próbowała - mimo formalnego ujęcia osobowości prawnej — wywodzić podmiotowość prawną w oparciu o inne podstawy, jednakże na tle legis latae miało to wątpliwe uzasadnienie. W rezultacie obowiązującej regulacji w doktrynie prawa cywilnego reprezentowane były poglądy kwestionujące w ogóle przydatność instytucji osoby prawnej, co świadczy o tym, że otoczenie prawne i stosowane mechanizmy tłumiły wszelką autonomię i niezależność interesu leżącą u podstaw odrębnej podmiotowości prawnej.

Pewnego rodzaju pozostałością wąskiego przyznawania osobowości prawnej w okresie PRL jest wyróżnianie w polskiej nauce prawa trzeciej — obok osób fizycznych i prawnych — kategorii podmiotów. Ma ona obecnie - po wprowadzeniu kategorii tak zwanych „osób ustawowych”48 jako jednostek organizacyjnych wyposażonych $\mathrm{w}$ zdolność prawną, ale nieposiadających osobowości prawnej — w polskim systemie prawnym swoje normatywne podstawy ${ }^{49}$. Obecnie osoby ustawowe nie są jednak odróżniane od prawnych ze względu na istnienie podmiotowość czy też jej zakres - mogą one stanowić podmiot praw i obowiązków taki sam jak osoby prawne — a różnicowane są z przyczyn dotyczących ich konstrukcji.

\section{Bibliografia}

Dzierzgwa H., Glosa do orzeczenia Sąu Najwyższego z dnia 7.06.1957, IV CR 185/56, „Orzecznictwo Sądów Polskich i Komisji Arbitrażowych" 1958, poz. 260.

Frąckowiak J., Instytucje prawa handlowego w kodeksie cywilnym, „Rejent” 2013, nr 6.

Gordon Z., Kwaśniewski Z., Łupuski J., Winiarz J., Prawo obrotu gospodarczego, Warszawa 1980.

Grzybowski S., Kilka uwag o rzekomych podmiotach stosunków cywilnoprawnych, „Studia Cywilistyczne" 27, 1976.

Grzybowski S., Ze studjów nad osobowościa prawną. Powstanie, rozwiazanie i likwidacja spótdzielni, Kraków 1930.

Janczewski S., Prawo handlowe, wekslowe i czekowe, Warszawa 1946.

Janik A., Osobowość prawna wspólnych przedsiębiorstw krajów RWPG, „Państwo i Prawo” 1977.

Klein A., Ewolucja instytucji osobowości prawnej, [w:] Tendencje rozwoju prawa cywilnego, red. E. Łętowska, Warszawa 1983.

Kodeks cywilny. Komentarz, red. M. Załucki, Warszawa 2020.

Kufel J., Siuda W., Prawo gospodarcze dla ekonomistów, Warszawa-Poznań 1980.

Longchamps de Bérier R., Studia nad istota osoby prawniczej, Lwów 1911.

Łętowska E., Samodzielność przedsiębiorstw i ich osobowość prawna, „Przegląd Ustawodawstwa Gospodarczego" 1971, nr 11.

48 Por. szerzej J. Frąckowiak, Instytucje prawa handlowego w kodeksie cywilnym, „Rejent” 2013, nr 6, s. 23 n.

49 Zgodnie $\mathrm{z}$ art. $33^{1} \mathrm{kc}$ do ,jednostek organizacyjnych niebędących osobami prawnymi, którym ustawa przyznaje zdolność prawną", stosuje się odpowiednio przepisy o osobach prawnych. 
Mądrzak H., Zdolność prawna a zdolność sądowa (uwagi wokół upodmiotowienia niektórych struktur organizacyjnych w prawie cywilnym i procesowym), [w:] II Kongres Notariuszy Rzeczypospolitej Polskiej. Referaty i opracowania, Poznań-Kluczbork 1999.

Misiuk T., Glosa do uchwaty z 7 VII 1966, III PZP 11/66, „Państwo i Prawo” 1967, nr 6.

Misiuk T., Pojęcie organizacji ludu pracującego, „Państwo i Prawo” 1969, nr 1.

Ohanowicz A., Zobowiazania. Zarys wedlug kodeksu cywilnego, Warszawa-Poznań 1965.

Prawo cywilne - część ogólna, t. 1, red. M. Safjan, Warszawa 2012.

Przymusiński C., Jeszcze jedna próba pogodzenia zasady jedności własności państwowej z zasada osobowości prawnej przedsiębiorstw państwowych, „Przegląd Ustawodawstwa Gospodarczego" 1966, nr 3.

Rada Legislacyjna przy Prezesie Rady Ministrów. Z problematyki skuteczności prawa gospodarczego i finansowego, Warszawa 1987.

Radwański Z., Podmioty prawa cywilnego w świetle zmian kodeksu cywilnego przeprowadzonych ustawa z dnia 14 lutego 2003 r., „Przegląd Sądowy” 2003, nr 7-8.

Radwański Z., Prawo cywilne - część ogólna, Warszawa 1994.

Rzepka E., Z problematyki osobowości prawnej, „Nowe Prawo”7-8, 1978.

Siedlecki W., Zarys postępowania cywilnego, Warszawa 1968.

Stelmachowski A., Czy kryzys osoby prawnej?, „Ruch Prawniczy, Ekonomiczny i Socjologiczny” 3, 1960.

Stelmachowski A., Wstęp do teorii prawa cywilnego, Warszawa 1998.

Włodyka S., Prawo gospodarcze. Zarys systemu. Część ogólna, t. 1, Warszawa 1981.

Wolter A., Nowy projekt kodeksu cywilnego, „Państwo i Prawo” 1962, nr 2.

Wolter A., Osobowość prawna jednostek budżetowych, „Państwo i Prawo” 1956, nr 11.

Wolter A., Prawo cywilne. Zarys części ogólnej, Warszawa 1967.

Wolter A., Zagadnienie osobowości prawnej w projekcie kodeksu cywilnego Polskiej Rzeczypospolitej Ludowej, [w:] Materiaty dyskusyjne do projektu kodeksu cywilnego Polskiej Rzeczypospolitej Ludowej. Materiały Sesji Naukowej, Warszawa 1955. 